\title{
OK18: Solidaritetspagt, musketer-ed, massemobilisering og tæt på storkonflikt i den offentlige sektor
}

\author{
Laust Høgedahl \& Flemming Ibsen
}

OK18 blev en af de mest højdramatiske overenskomstfornyelser i den offentlige sektors historie. Overenskomstforhandlingerne kom i helt nye situationer, som ikke var prøvet før. Alle tre områder: stat, kommuner og regioner endte alle i Forligsinstitutionen på samme tid, og begge parter varslede konflikt. I denne artikel undersøger vi - via kvalitativt data kombineret med teori om magtressourcer - hvorfor det kom så vidt, og hvordan det til trods for højspoendte forhandlinger alligevel lykkes parterne at indgå forlig.

Nøgleord: OK18, Den danske model, offentlige overenskomstforhandlinger

\section{OK18 - En historisk overenskomstfornyelse}

Overenskomstforhandlingerne i den private sektor er - bortset fra storkonflikten i 1998 - forløbet ret så udramatisk både i 'nullerne' under højkonjunkturen og under og efter finanskrisen fra 2008. Faktisk oplever den private sektor et historisk lavt konfliktniveau målt på tabte arbejdsdage (Høgedahl, 2019). Parterne har fundet hinanden i forlig, der er blevet stemt hjem med store ja-flertal i de fleste tilfælde. Anderledes er overenskomstforhandlingerne forløbet i den offentlige sektor. På toppen af højkonjunkturen i 2008 - før den globale finanskrise brød ud og ramte dansk økonomi relativt hårdt - indgik parterne i den offentlige sektor et forlig i stat, regioner og kommuner, der gav lønmodtagerne relativt store reallønsstigninger, men først efter længerevarende konflikter blandt sosu-assistenterne, sygeplejersker og pædagogernes områder (Jakobsen \& Pedersen, 2010, Stamhus et al., 2010). Igen i 2013 oplevede den offentlige sektor - for første gang i sektorens historie - en offensiv storlockout på lærerområdet, der blev afsluttet af et lovindgreb (Høgedahl \& Ibsen, 2015). I 2015 indgik parterne forlig hele vejen rundt, der blev stemt hjem, men i virkeligheden var man meget tæt på en storkonflikt efter dramatiske forhandlinger (Høgedahl, 2019).

Den offentlige sektors overenskomstforløb har således været meget konfliktfyldt i perioden fra 2008 til 2015, men offentligheden forventede et relativt fredeligt OK18 forløb med start i slutningen af 2017. Dansk økonomi var ude af finanskrisen, de private overenskomstforhandlinger i 2017 var afsluttede med forlig og pæne reallønsstigninger, som man kunne forvente ville blive overført til de offentlige overenskomstforhandlinger uden de store problemer. Men virkeligheden 
blev en ganske anden. OK18 blev et af de mest dramatiske forhandlingsforløb i sektorens historie, hvor man var meget tæt på danmarkshistoriens største konflikt i den offentlige sektor.

Denne artikels formål er at beskrive og analysere OK18 forløbet og besvare forskningsspørgsmålene: Hvorfor blev både opstarten og forløbet så konfliktfyldt og dramatisk, hvilke faktorer var afgørende for, at fagbevægelsen denne gang kunne mobilisere så mange medlemmer bag deres krav, og hvorfor skiftede fagbevægelsen strategi og udviklede en solidaritetspagt, som senere blev til en musketer-ed? Hvor tæt var man på en storkonflikt omfattende både stat, regioner og kommuner? Hvorfor blev der alligevel indgået forlig, og storkonflikten afløst af arbejdsfred, efter at afstemningsresultaterne med meget høje ja-flertal var en realitet?

I næste afsnit præsenteres artiklens teoretiske ramme efterfulgt af den anvendte metode og datagrundlag. Herefter følger en analyse af de væsentlige rammebetingelser for OK18: De internationale konjunkturer og fremtidsudsigterne for dansk økonomi, resultatet af de private overenskomstforhandlinger i 2017, og de politiske konjunkturer på Christiansborg. Dernæst analyseres, hvordan resultaterne fra de seneste overenskomstrunder i den offentlige sektor kan tænkes at påvirke forløbet under OK18. Efterfølgende analyseres optakten til og forløbet af OK18, forligenes resultater og indhold. Artiklen afsluttes med en konklusion og en perspektivering, der behandler, hvordan OK18 kan tænkes at påvirke de kommende overenskomstforhandlinger?

\section{Mobilisering og magtressourcer i et institutionelt perspektiv}

For at besvare forskningsspørgsmålene præsenteret ovenfor trækker vi på magtressour- ceteori i et historisk-institutionelt perspektiv. Et centralt spørgsmål i forskningslitteraturen omkring arbejdsmarkedsrelationer har i mange år været, hvad der får magtpendulet til at svinge til fordel for enten arbejdsgiverne eller lønmodtagerne i arbejdskampen, og hvad der påvirker udfaldet af overenskomstforhandlinger (Pedersen 1997; 1999; Petersen 1987). Her findes en lang række teoretiske bud, der både fokuserer på strukturelle forhold (som fx den økonomiske situation), institutioners betydninger (fx Forligsinstitutionen eller forhandlingsstrukturen) og ikke mindste aktørernes præferencer, interesser og strategier i forhandlingerne (Scheuer, 2010) . I Dunlops (1958) berømmede systemteori er overenskomsternes resultat et 'output' af flere forhold eller rammebetingelser. Det gælder bl.a. den økonomiske og politiske situation, teknologi, og hierarkiet på henholdsvis arbejdsgiver- og lønmodtagersiden, (Ibsen og Stamhus, 1993). Senere teori har siden haft et større fokus på aktørerne i modellen deres interesser og strategier (Kochan et al., 1984). Forskningen har også været koncentreret omkring, hvordan og hvorfor særligt lønmodtagere vælger at gå sammen i faglige organisationer, og hvordan disse kan sætte sig igennem overfor deres arbejdsgivermodpart (Kelly, 1998; Edwards, 2006). Magt er her et centralt forhold, der ofte tager udgangspunkt i et ressourceperspektiv, hvor magten i arbejdskampen er betinget af en række forhold, som kan give enten den ene eller den anden part en fordel (Silva, 2003). I litteraturen skelnes imellem en række forskellige magtressourcer (Korpi, 1981), hvor forskningen viser, at der er ganske stor forskel på hvilke ressourcer, der er på spil og virker afgørende på tværs af den private - og den offentlige sektor (Høgedahl, 2019). I udgangspunktet gælder først og fremmest den strukturelle magtressource, som også betegnes som primær magt. Her har arbejdsgiverne i både den private og den offentlige 
sektor i udgangspunktet en særlig privilegeret magtposition på arbejdsmarkedet qua ledelses- og dispositionsretten, men magtpositionen påvirkes også af andre forhold, f.eks. konjunkturelle udsving i økonomien og reguleringer af løn - og arbejdsvilkår, (Ibsen, Høgedahl \& Scheuer, 2016). Forhold som økonomisk krise og en høj arbejdsløshed styrker arbejdsgiversiden magtmæssigt og mindsker lønmodtagernes og dermed fagforeningernes magt, mens det omvendte er tilfældet, hvis der er mangel på arbejdskraft (Hyman, 2008). Udover den strukturelle magtressource, der udspringer af ledelsesog dispositionsretten, så findes der også en række mere sekundære magtressourcer, heriblandt den organisatoriske magtressource, der dækker særligt lønmodtagernes evne til at optræde og handle enigt og kollektivt, til at mobilisere medlemmer og til at iværksætte kollektive aktioner for deres interesser. Den organisatoriske magtressource er traditionelt set blevet målt på organisationsgraden (dvs. andelen af lønmodtagere, der er medlem af en fagforening) og overenskomstdækning (dvs. andelen af arbejdsmarkedet der er dækket af en kollektiv overenskomst). Jo flere medlemmer og overenskomster - jo stærkere organisatorisk magtressource. Den organisatoriske magtressource kan imidlertid også være et udtryk for, hvor gode (eller dårlige) organisationer er til at koordinere krav (Lévesque \& Murray, 2006). Det samme gælder mobilisering, der iflg. Kelly (1998) kun kan opstå, når en gruppe (fx lønmodtagere) oplever en uretfærdighed, der kan italesættes og tilskrives en anden gruppe $\mathrm{fx}$ arbejdsgivere (Kelly, 1998).

I Danmark er den institutionelle magtressource også yderst relevant. Det skyldes først og fremmest, at 'den danske model' sætter afgørende institutionelle rammer for overenskomstforhandlingerne (Høgedahl, 2019; Ibsen \& Christensen, 2001). I Danmark er arbejdskampen og overenskomstforhand- linger i høj grad institutionaliseret. Forstået på den måde, at parterne har klare aftaler om, hvornår, hvordan og under hvilke omstændigheder, at konfliktvåbnene kan anvendes. Denne institutionelle ramme for forhandlingerne er i Danmark udviklet i den private sektor og først relativt sent indført på det offentlige område. Det gælder også Forligsinstitutionen, som spiller en afgørende rolle i koordinering og konfliktløsning på det danske arbejdsmarked i forbindelse med overenskomstfornyelser. Parternes organisering er også ganske anderledes i den offentlige sektor, hvor forhandlingsstrukturen fra tjenestemandssystemet betyder, at forhandlingsfællesskaber og centralorganisationer spiller en særlig vigtig rolle. Den sidste magtressource nemlig den kommunikative, spiller også en helt afgørende rolle på det offentlige område, og som også er tilsvarende blevet vigtigere i takt med medialiseringen af overenskomstforhandlingerne. Offentlige arbejdsgivere kan ikke på samme måde som i den private sektor rammes økonomisk af en konflikt, hvorfor den politiske kapital er afgørende. Det handler om at sætte en dagsorden bag ens krav, der kan skabe opbakning i folkehavet.

\section{Kvalitativ metode via interviews og dokumentstudier}

Denne artikel trækker på to datakilder via interviews og dokumentstudier. Interviewene er indhentet specifikt til denne artikel i perioden umiddelbart efter OK18 i juni 2018 frem til december 2018. I alt 16 interviews er gennemført af ca. 1 time til 1 1/2 times varighed. De interviewede informanter tæller repræsentanter for både arbejdsgivere og lønmodtagere. Alle informanter har i hele forløbet været tæt på forhandlingerne, hvilket har også været det centrale udvælgelseskriterie. Informanterne er blevet interviewet ud fra en semistruktureret interviewguide, hvor en 
del af spørgsmålene er operationaliseret ud fra den anvendte teori præsenteret ovenfor, mens andre går på specifikke oplevelser eller vurderinger af bestemte forhold og forløb omkring OK18 (Kvale \& Brinkmann, 2009). I artiklen citeres der ikke fra interviewene direkte. Det skyldes, at mange af emnerne, der behandles i interviewene, kan være prekære og ømtålelige. Ved ikke at benytte direkte citater i analyserne, er det lettere at opnå en større fortrolighed mellem forsker og informant og dermed indsigt. Ulempen ved ikke at benytte direkte citater, er, at interviewene ikke kan blive foldet helt ud i analyserne. For et lignende studie med samme metodiske tilgang se evt. Ibsen (2010; 2013). Der trækkes på interviewdata, hvis ikke andre referencer er angivet.

I supplement til interviewene bygger artiklens datagrundlag også på et kvalitativt dokumentstudie, der især trækker på dokumenter offentliggjort af parterne selv herunder notater om krav, resultater af forligene og pressemeddelelser udsendt både før, under og efter forhandlingerne. Udvælgelsen af dokumenter er sket på baggrund af relevans for belysning af forhandlingsforløbet, hvor særligt pressemeddelelser leverer afgørende indsigt i parternes positioner og adfærd.

Analysen følger forhandlingernes kronologi. Dvs. vi indleder med rammebetingelser efterfuldt af optakt, forhandlinger, sammenbrud og forlig. I konklusionen vender vi i høj grad tilbage til det teoretiske udgangspunkt præsenteret ovenfor.

\section{Rammebetingelserne for OK18}

De primære rammer for OK18 er de internationale konjunkturer og dansk økonomis tilstand ved årsskiftet 2017/2018 og frem mod 2021, de 'politiske konjunkturer' på Christiansborg og - ikke mindst - den historiske ballast i form af forløbet og resultatet af de foregående OK-runder efter krisen i 2008.
Forventningerne til den danske økonomi er klart en af de allervigtigste rammebetingelser for forhandlingerne. Iflg. Det Økonomiske Råds Årsrapport fra 2017 vil væksten i vores aftagerlande ligge på omkring 2 procent i perioden fra 2017 - 2021, og den danske beskæftigelse vil vokse markant i samme periode. Væksten i produktionen vil primært ske i den private sektor, medens væksten i den offentlige sektor, målt som procent af BNP, vil ligge mellem 0 og minus 1 procent. Timelønsvæksten skønnes at ligge mellem 2 og 3 procent med en stigende tendens, medens inflationstakten vil ligge mellem 1 og 2 procent (DØR, 2017, s. 2).

Den samlede vurdering fra de økonomiske vismænd er, kort før OK18 blev skudt i gang, at dansk økonomi er ude af finanskrisen og i topform med en pæn og konstant vækst i både produktion og beskæftigelse, men hvor væksten helt overvejende kommer i den private sektor. Vismændene forudser også reallønsstigninger, da de nominelle lønstigninger vil overstige inflationen med lidt over 1 procentpoint. Beskæftigelsen forudsættes dog næsten udelukkende at stige i den private sektor, men de offentligt ansatte vil derimod kunne forvente, at der vil være plads til både nominelle og reelle lønstigninger i 2017, 2018 og 2019.

Den danske løndannelsesmodel benævnes ofte som en 'frontfagsmodel' (Nergaard m.fl. 2016; Ibsen, 2016; Høgedahl, 2019), som indikerer, at 'frontfaget', i en dansk og nordisk kontekstindustri, skal være normsættende for udviklingen i det gennemsnitlige lønniveau i båden den private og offentlige sektor. Industrien skal, som det konkurrenceudsatte erhverv, være lønførende, og den offentlige sektors lønudvikling skal indordne sig under denne norm. Når de offentlige forhandlere sætter sig til forhandlingsbordet, har parterne derfor en forestilling om, hvor meget industriens lønniveau i den private sektor vil stige i perioden fra 2017 til 2020. Udgangs- 
punktet for OK18 i den offentlige sektor vil derfor være et skøn over den gennemsnitlige lønstigningstakt på LO/DA-området i den private sektor. Ingen let opgave, da løndelen i praksis er taget ud af de centrale overenskomstforhandlinger mellem DI og COI. Centralt aftaler parterne alene stigninger i mindstelønnen - som kun en meget lille del af de ansatte dog arbejder på. Udviklingen i de faktiske lønninger aftales gennem lokale forhandlinger på den enkelte arbejdsplads. De offentlige forhandlere kan derfor ikke aflæse den forventede lønstigningstakt i industrien ved blot at analysere resultatet af OK17 på DI-COI's område. Her er aftalt, at mindstelønnen på 113,65 kr. skal stige med 6 kr. fra 01.03.17 til 01.03.19, hvilket giver en stigning på lidt under 6 procent. Hertil kommer en forbedring af fritvalgskontoen, hvor indbetalingerne vokser fra 0,7 til 4,0 procent af den ferieberettigede løn, og alt i alt kan man skønne, at de rene løngoder vil betyde en procentvis stigning på lidt under 7,5 procent fra 01.03.2017 til 01.03.2019. Oveni skal lægges en række sociale goder; flere seniorordninger, i alt 2 børneomsorgsdage, fuld løn under forældreorlov, bedre forhold for vikarer, og bedre efteruddannelsesmuligheder. Man kan dog ikke aflæse den forventede lønstigningstakt i industrien ved alene af kigge på aftaleteksten. Resultatet af de lokale lønforhandlinger afhænger ikke mindst af konjunkturudviklingen i den internationale - og den danske økonomi, og sammen med adgangen til udenlandsk arbejdskraft i EU og det øgede arbejdsudbud er det ganske vanskeligt at skønne over lønudviklingen i den private sektor.

\subsection{De politiske vinde på Christiansborg}

På Christiansborg har der - efter valget i juni 2015 og et regeringsskifte fra Thorning-rege- ringen til en ren Venstreregering - hersket en politisk dagsorden om, at væksten i dansk økonomi primært skulle ske i den private sektor, og at råderummet for en ekspansion i den offentlige sektor var beskedent. Gennemførelsen af et omprioriteringsbidrag på to procent i alle dele af den offentlige sektor byggede på, at ekspansion på et sted måtte gå hånd i hånd med besparelser et andet sted. Effektiviseringer og rationaliseringen førte mange steder til afskedigelser, og rummet for lønstigninger fra OK15 var beskedent. Den nyudnævnte Innovationsministers opgave var primært at udvikle en ny og mere dynamisk samt effektiv ledelsesform i den offentlige sektor via resultater fra den nedsatte Ledelseskommission. Arbejdet med at skabe højere kvalitet i leveringen af offentlige serviceydelser skulle bl.a. ske gennem markante ændringer i de offentlige overenskomster. I oktober 2017 sendte de statslige arbejdsgivere via Moderniseringsstyrelsen (MS) et brev til lønmodtagerne via CFU (Centralorganisationernes Fællesudvalg), hvori man påpegede, at man ikke anerkendte CFU's fortolkning af en voldgiftskendelse om DR's betalte spisepause. Kendelsen gav lønmodtagersiden ret $i$, at de havde en overenskomstmæssig ret til deres betalte spisepause, en ret, som DR's ledelse havde anfægtet. Ifølge arbejdsgiverne tolkede CFU kendelsen som at den dannede præcedens for alle statsansatte, og at den betalte spisepause nu kun kunne fjernes via en overenskomstforhandling. MS gjorde i brevet gældende, efter råd fra kammeradvokaten, at de tolkede kendelsen anderledes, og at DR-kendelse ikke dannede præcedens for de øvige statsansatte. Retstilstanden var derfor, at hovedparten af de statsansatte er omfattet af lokale kutymer om betalte spisepauser, der - som øvrige personalegoder - kan opsiges af arbejdsgiverne uden en overenskomstforhandling. Denne fortolkningskonflikt om spisepausernes retstilstand skabte en dårlig stemning mellem de statslige forhandlere, 
og kom oveni tidligere kutymesager, hvor arbejdsgiverne ensidigt havde opsagt kutymefridage i social- og indenrigsministeriet og derefter kørt og vundet voldgiftssagerne tilbage i efteråret 2016 (Høgedahl, 2019). MS følte imidlertid, at man var tvunget til at udfordre CFU's fortolkning af DR-kendelsen, da tavshed ville kunne fortolkes som en accept. Men vores interviews dokumenterer, at MS har fortrudt selve timingen af brevforsendelsen.

Generelt er politikerne på Christiansborg tilbageholdende med at udtalelse sig om de kommende overenskomstforhandlinger ud fra devisen om, at 'den danske model er en aftalemodel, som politikerne skal holde fingrene væk fra'. Forhandlingerne skulle starte i slutningen af 2017 og afsluttes foråret 2018, og da folketingsvalget skal afholdes senest den 15. juni 2019, og valgkampen derfor ville starte allerede foråret 2018, ville det være fristende for Christiansborg-politikerne at blande sig i forhandlingsforløbet, når det først var kommet i gang. De ca. 800.000 offentligt ansatte udgør en betragtelig stor del af det potentielle vælgerkorps, og derfor vil det være fristende at komme med sympatitilkendegivelser, før eller når spillet er kommet i gang. Og det skete da også, jævnfør nedenfor. Det lurerne folketingsvalg betød, at den kommunikative magtressource skulle blive særlig afgørende for OK18. Statsminister Lars Lykke Rasmussen udtalte fra talerstolen ved Folketingets åbning, at 'det går godt i dansk økonomi' med reference til de økonomiske nøgletal og en prognose, der pegede på, at det økonomiske råderum var på 25 mia. kr. frem mod 2025. Krisestemningen blandt politikerne var vendt til optimisme, et stemningsbillede, der også bredte sig til både medlemmerne og forhandlerne i de offentlige fagforbund.

\subsection{De tidligere overenskomstrunder}

Udover den politiske stemning på Christiansborg, så spiller de tidligere overenskomstrunder ligeledes en afgørende rolle. Forhandlerne sker ikke på et tabula rasa, men er i høj grad bestemt af tidligere forhandlingsrunder. Due og Madsen (2009) betegner denne afhængighed som overenskomstforhandlingernes-koededans, mens den norske arbejdsmarkedsforsker Torgeir Stokke (1998) betegner det som traditionernes magt. I et historisk-institutionelt perspektiv kaldes dette forhold for sti-afhængighed (Pierson, 2000).

Under OK08 var de faglige organisationers hovedkrav generelle lønstigninger, der modsvarede den daværende højkonjunkturs store økonomiske råderum, suppleret med særlige lavtløns- og ligelønspuljer. Specielt ligelønskravet blev fremsat med stor styrke af kvindegrupperne i FOA, DSR og BUPL, og da de tre grupper ikke var tilfredse med Det generelle KTO-forligs samlede lønramme gik de tre forbund ud i en lønstrejke, der ikke blev modsvaret af en lockout fra arbejdsgiversiden. Ligelønskravet havde stor opbakning både i offentligheden og på Christiansborg. Konflikterne blev stærkt politiserede, men endte til manges overraskelse ikke med et lovindgreb men med forlig mellem parterne på alle tre områder (Stamhus et al., 2010).

OK11 blev et overenskomstforløb i finanskrisens tegn, hvor lønmodtagerne var i defensiven, da de relativt store lønstigninger, som man opnåede på toppen af højkonjunkturen i 2008, nu stod til at blive rullet tilbage, (Ibsen, Høgedahl \& Scheuer, 2016). Den private sektors lønninger dykkede omgående, da krisen slog igennem med fuld kraft i starten af 2009, og afmatningen fortsatte i 2010 og 2011. Reguleringsordningens måde at fungere på ville betyde en direkte lønnedgang for de offentligt ansatte, men 
parterne endte med en aftale om en nul-regulering for ikke at udsætte de offentligt ansatte for en direkte lønnedgang, som ellers var konsekvens af reguleringsordningens udmøntning. Her blev kimen lagt til en senere konflikt om udviklingen i og relationen mellem det offentlige og private lønniveau, som både kom til at præge OK15 og ikke mindst OK18. En anden udløber af OK11 var en forværring af samarbejdsklimaet mellem CFU og de statslige arbejdsgivere. Man havde aftalt et serviceeftersyn af den danske model, men man kunne ikke enes om et fælles konkluderende papir og endte med to udtalelser, der understregede, hvad konflikten drejede sig om: forholdet mellem arbejdsgiverens ledelsesret og aftaleretten mellem parterne, herunder tillidsrepræsentantssystemets og samarbejdsudvalgets status. Kimen til en dårlig samarbejdsrelation mellem de statslige aktører i den danske model var hermed lagt.

OK13 fik sit helt eget og dramatiske forløb med danmarkshistoriens første offensive arbejdsgiverlockout i den offentlige sektor. En folkeskolereform med vægt på mere magt til skoleledelsen og mere fleksible lokale arbejdstidsregler blev under OK13 fulgt op af en konflikt på lærerne og undervisernes område. Arbejdsgiverne udsendte og iværksatte en storlockout på hele LC's (Lærernes Centralorganisation) område, og Folketinget afsluttede konflikten med et lovindgreb, der lå tæu op ad KL's (Kommunernes Landsforening) og de øvrige arbejdsgiveres krav. Lov 409, som loven kom til at hedde, erstattede nu de gældende overenskomster og blev det regelsæt, der nu var styrende for arbejdets tilrettelæggelse og udførelse på undervisningsområdet og ikke mindst på DLFs (Danmarks Lærerforening) og folkeskoleområdet. DLF havde kørt konflikten og tog tæskene alene, da man ikke havde bedt de øvrige forbund om at iværksætte sympatistrejker mod arbejdsgiverparten. Det er derfor næppe en forkert vurdering at hævde, at mange af forbundene følte, at de skyldte DLF en solidaritetsomgang.

Den kom ikke under OK15, hvor forbundene nok følte, at man var for tæt på OK13. Men OK15 fik på trods af, at parterne stadig befandt sig i en kriseøkonomi, et dramatisk forløb, der også kom til at sætte rammen for OK18. Finansmisteriet smed sent i forhandlingsforløbet et notat på bordet, der viste, at de offentlige lønninger var steget mere end de private, hvilket var i modstrid med 'frontløberstrategien' og reguleringsordningens funktionsmåde. For at undgå en storkonflikt måtte de faglige forhandlere acceptere et såkaldt 'Privatlønsværn', der ændrede reguleringsordningen i fagbevægelsens disfavør. Hvis de offentlige lønninger steg hurtigere end de privates, skulle de offentlige lønninger nedreguleres med 100 procent af forskellen, hvis det modsatte var tilfældet, skulle de offentlige lønninger kun stige med 80 procent af forskellen. I tilslutning til Privatlønsværnet måtte de faglige ledere med formanden for CFU Flemming Vinther i spidsen underskrive en erklæring om, at parterne er enige om, at det er en fælles målsætning at bringe den i 2008 indledte forskel i lønudviklingen mellem private og statslige til ophør i den næstkommende overenskomstperiode. Havde fagbevægelsen ikke accepteret Privatlønsværnet og underskrevet hensigtserklæringen, gik udviklingen mod storkonflikt. Man skrev altså under med pistolen for panden og under protest, da man ikke anerkendte finansministeriets regnestykke om, at medlemmerne skyldte penge til statskassen. Men papiret med underskriften blev gemt i finansministeriet, og det blev ikke glemt, da man startede OK18.

På folkeskoleområdet pressede DLF KL for at få byttet Lov 409 om med aftalestof, men man endte kun med nogle hensigtserklæringer i et bilag til aftalen, der ikke ville holde i Arbejdsretten. Lov 409 var stadig gældende, selv om der på mange folkeskoler og i 
mange kommuner var blevet lavet lokale arbejdstidsaftaler, der blødte op på lov 409's regelsæt.

\subsection{Sammenfatning af rammebetingelserne for OK18 $i$ den offentlige sektor}

Både de økonomiske og politiske konjunkturer - historisk og aktuelt - satte rammerne for OK18 og prægede både optakten, forløbet og resultatet. Aktuelt var dansk økonomi i topform i 2017 og 2018, og der var derfor både forventninger om og udsigt til pæne lønforhøjelser, både nominelt og realt, hvilket OK17 i den private sektor også lagde op til. Men Privatlønsværnet og den fælles hensigtserklæring om, at man var forpligtet til at fjerne løngabet i den kommende overenskomstperiode, stod i vejen for forventningen om store lønstigninger de næste 3 år. Desuden havde man et uforløst problem fra OK13, hvor lærerne var kørt over og - som det eneste forbund - fik reguleret deres arbejdstid af en lov og ikke af en overenskomst. Når det gjaldt kravenes prioritering, var det stadig en topprioritet at følge op på lavt- og ligelønskravene helt tilbage fra OK08. I tilgift havde MS - ufrivilligt - bragt status for de betalte spisepauser højt på listen over de temaer, som de offentlige forbund, herunder særligt akademikerne, ønskede at forhandle med deres arbejdsgivermodpart. Men det krav, der gik på tværs af de tre sektorer og var fælles for de ca. 800.000 lønmodtagere i den offentlige sektor, var uden tvivl at opnå lønstigninger, der matchede de lønstigninger, som deres kolleger i den private sektor havde opnået i 2017. Det økonomiske råderum var til stede og politikernes vilje til at dele ud af det ville sikkert være påvirket af, at et folketingsvalg ikke var alt for langt væk.

\section{Parternes krav}

Parterne i staten, regionerne og kommunerne havde i løbet af 2017 arbejdet med at formulere deres krav til OK18, og kravene kan opdeles i nogle generelle - og nogle organisationsspecifikke krav, der begge skal kunne rummes inden for den aftalte ramme i de store forlig, indgået mellem CFU - MS i staten, KL - FF (Forhandlingsfællesskabet) i kommunerne og FF - Regionerne/RLTN. Parterne på begge side har tradition for at koordinere deres krav og forhandlingsstrategi. På arbejdsgiversiden er det staten, dvs. Finansministeriet, (FM) via MS, der udstikker den ønskede økonomiske ramme for forligene i både staten, kommunerne og regionerne. På lønmodtagersiden koordineres kravene af FF i kommunerne og regionerne mens CFU koordinerer kravene på statens område (Høgedahl, 2019).

Arbejdsgiversidens krav til OK18:

- En økonomisk ansvarlig lønramme

- Lukning af løngabet mellem det offentligt og privatansatte, aftalt i hensigtsserklæringen fra OK15, (alene staten)

- Forenkling af overenskomstsystemet, færre overenskomster og tillidsrepræsentanter, færre møder

- Kompetenceudvikling af de ansatte, svarende til fremtidens arbejdsmarked og ny teknologi

- Tidssvarende lønsystemer og mere lokal og individuel løndannelse

- Større rum for ledelse og udvikling af leder- og chefoverenskomster

- Mulighed for rekruttering af den nødvendige og kvalificerede arbejdskraft (MS, 2017; KL, 2017; Regionerne, 2017)

Lønmodtagersiden krav til OK18:

- Forbedring af reallønnen, følge med de privatansattes lønudvikling 
- Særlige ligeløns- og lavtlønspuljer

- Fortsættelse af 'fra ufaglært til faglært projektet'

- Forbedring af arbejdsmiljøet

- Fritvalgskonto (efter privat forbillede)

- Ligestillingen skal forøges

- Omsorgsgoder, familie-/arbejdsliv

- Tryghedsgoder

- Ret til betalt spisepause (CFU, 2017; FF, 2017)

Kravenes betydning varierer fra sektor til sektor og fra område til område, men det mest betydningsfulde og tværgående krav på begge sider af forhandlingsbordet var lønrammens størrelse. Hertil havde arbejdsgiverne tilføjet et krav om at indfri løftet i Hensigtserklæringen fra OK15 om at lukke løngabet mellem offentligt og privatansatte, et krav, som hurtigt stjal dagsordenen, da kravene blev udvekslet i december måned 2017. Lønmodtagersiden havde på sin side et fælles krav om at få bekræftet den betalte spisepause som en overenskomstmæssig rettighed, et krav, der også hurtigt kom højt op på forhandlernes prioriteringsliste.

Et afgørende spørgsmål er hvilke krav, der kan tolkes 'konfliktudløsende'. Forstået som, at hvis én af eller begge parter ikke får opfyldt de(t) krav, vil man trække konfliktvåbnet $\mathrm{i}$ form af en strejke eller en lockout eller begge dele?

Når det gælder arbejdsgiversiden, både staten, KL og Regionerne (som staten også styrer via sin vetoret i RTLN), er det i udgangspunktet Finansministeren, der via Innovationsministeren og MS bestemmer, hvornår der skal trykkes på lockoutknappen, hvis man ikke får opfyldt sit hovedkrav, der er 'en ansvarlig lønramme', gældende for alle tre sektorer. Rammen er resultatet fra OK17 i den private sektor, men man kan ikke direkte - som anført ovenfor - aflæse lønudviklingen af industriforliget, da lønnen aftales via lokale forhandlinger på virksomhedsniveau.
Så arbejdsgivernes ansvarlige lønramme bygger på det bedste skøn over den private sektors lønudvikling fra 2017 til 2020.

Når det gælder fagbevægelsen, er det mere usikkert, hvilke krav, der på forhånd er udtaget som konfliktudløsende, da de forskellige faggrupper og forhandlingsfællesskaber både har fælles og divergerende interesser. Men i en pressemeddelelse fra den 27. juni 2017 skriver FF: 'Vi har i forhandlingsfællesskabet givet hinanden håndslag på, at ingen organisation ville blive efterladt på perronen i de kommende forhandlinger. Håndslaget indebærer, at vi i fællesskab bl.a. vil sikre, at alle organisationer skal have muligheder for at komme i reelle forhandlinger. Kommer vi i en situation, hvor det er nødvendigt at bruge det politiske håndslag, så vil vi konkret tage stilling til, hvordan vi vil følge op overfor arbejdsgiverne'. Dette håndslag fra FF er tydeligvis en støtteerklæring til DLF og deres kamp for en arbejdstidsoverenskomst, og den følges op af hele fagbevægelsen i den offentlige sektor den 6 . oktober 2017 i brevet til de offentlige arbejdsgivere, jf. ovenfor, hvori CFU og FF meddeler, at DLF skal i realitetsforhandlinger med KL før man overhovedet vil starte på at forhandle overenskomster. Men vil disse to støtteerklæringer til DLF betyde, at den samlede fagbevægelse ville gå ud i en totalomfattende storkonflikt i stat, kommuner og regioner, hvis DLF ikke fik en ny arbejdstidsoverenskomst, der tilfredsstillede DLF? Det er uklart, og det blev aldrig afprøvet under OK18 (jf. nedenfor).

Det tætteste, man kommer en erklæring om et konfliktudløsende krav, er FF's vedtagelse den 2. marts 2018: 'Derfor er alle faglige organisationer for Danmarks offentligt ansatte parate til at gå i konflikt for at sikre det meget afgørende kernepunkt i overenskomsterne, en fremgang i reallønnen som er parallel til lønudviklingen i den private sektor'.

Men udtalelsen dækker alene FF, der omfatter regioner og kommuner, og altså ikke 
CFU i staten. FF og CFU kom ikke med en fælleserklæring før forhandlingernes start om, hvilke krav der var konfliktudløsende, men under forhandlingerne dukker der begreber op i medierne som 'solidaritetpagt' og 'musketered', og sloganet 'En løsning for alle', der indikerer, at den samlede fagbevægelse havde en fælles opfattelse af, hvilke krav, der var konfliktudløsende. Kravene udvikler sig efterhånden som det bliver klart, hvor knasterne findes i de tre sektorer, men det var ikke før forhandlingernes begyndelse helt tydeligt, hvilke krav den samlede fagbevægelse i fællesskab ville gå ud i en altomfattende storkonflikt for at forsvare. Efter forhandlingerne gik i gang bliver det dog hurtigt klart, at Akademikerne (AC) var klar til at gå i konflikt for en acceptabel løsning på striden om den betalte spisepauses retstilstand. DLF ville heller ikke - som under OK13 - acceptere at blive kørt fuldstændigt over af KL og regeringen. Men det tætteste man kommer på et fælles, tværgående konfliktudløsende krav for hele fagbevægelsen før forhandlingerne gik i gang, var lønkravet, defineret som en lønramme, der matchede den private sektors skønnede lønudvikling, plus ligeløns- og lavtlønskravet og en fjernelse af Privatllønsværnet og 'gælden' fra OK15. I interview med parterne er der dog forskellige opfattelser af hvilke krav, der skulle fortolkes som konfliktudløsende.

\section{Konfliktfyldt opstart}

Parterne i stat, regioner og kommuner havde som vanligt aftalt en køreplan for forhandlingerne, hvor man skulle udveksle krav i midten af december måned 2017. Derefter skulle de organisationsspecifikke forhandlinger starte og i begyndelsen af januar ville FF og KL starte forhandlinger om de generelle spørgsmål. Regionerne og staten fulgte nogenlunde det samme tidsmønster, og på KL og FF's område skulle de organistions- specifikke forhandlinger være påbegyndt omkring den 25. januar 2018. Ifølge køreplanen skulle hovedforhandlingerne mellem KL og FF være afsluttet senest den 14. februar og de organisationsspecifikke forhandlinger senest den 28. februar. Der blev også fastsat en tidsramme for varsling af konflikter inden overenskomsternes udløb den 01.04.2018, og hvornår forhandlingerne skulle overgå til Forligsinstitutionen.

Den aftalte køreplan blev dog meget hurtigt fraveget. CFU og FF ville - jævnfør ovenfor - ikke starte forhandlingerne før LC tilkendegav, at man nu var i realitetsforhandlinger med KL. LC tilkendegav først den 23. januar 2018, at man nu var i realitetsforhandlinger med KL om arbejdstidsspørgsmålet, og dermed blevet starten på forhandlingerne forsinket med en måned i forhold til køreplanen. Ikke den bedste og mest tillidsfulde start på et overenskomstforløb, men det skulle blive værre endnu. Arbejdsgiverne hev Hensigtserklæringen fra OK15 frem af skuffen og præsenterede den for fagbevægelsen og offentligheden, bakket op af DA (Dansk Arbejdsgiverforening), som hævdede at have dokumentation for, at reguleringsordningen ikke virkede efter hensigten og havde tilgodeset lønmodtagersiden.

Men chefforhandler for arbejdsgiversiden på statens område Innovationsminister Sophie Løhde blev efterfølgende mødt med massiv kritik. Lønmodtagerne bestred løngabets eksistens og fremlagde en lønstatistisk dokumentation med basisår 1996 som udgangspunkt, mens MS og Løhde brugte 2008 som basisår. CFU råbte 'hokus-pokus' om Løhdes dokumentation, og konflikten om løngabet og de 6 mia kr. som lønmodtagerne på forhånd skulle betale tilbage, fik sit eget liv på de sociale medier, hvor offentligt ansatte præsenterede deres lønseddel under hashtaget \#Sophieslønfest, som en sygeplejerske startede efterfulgt af ansatte i forsvaret, yngre læge, politibetjente om mange andre 
faggrupper (Interview). Offentligheden var tilsyneladende ikke klar over, at Flemming Vinther på CFUs vegne faktisk havde skrevet under på en aftale om at lukke løngabet i den næste overenskomstperiode, dvs. ved OK18. Hele løngabsdiskussionen var med til at mobilisere fagbevægelsens medlemmer, hvoraf mange fik luft for deres frustrationer over mange års effektiviseringer og et øget arbejdspres. Fagbevægelsen slogan 'Nok er Nok' samlede det hele. Arbejdskampen i medierne viste, hvor vigtig den kommunikative magtressource er, og hvordan de sociale medier her indtager en ny og afgørende rolle i forhold til mobilisering og 'framing' af synspunkter og krav overfor den brede befolkning.

\section{Forhandlingsforløbet - Solidaritetspagt, musketered, sammenbrud og konfliktvarsler}

Forhandlingerne gik nu gang i alle sektorer og på alle niveauer, men det viste sig hurtigt, at forhandlingsforløbet ikke ville blive, som det plejede at forløbe. I den private sektor er det - som beskrevet oven for - industrien, der typisk skaber gennembrudsforliget, der kan skabe dynamik i hele forhandlingsspillet og sætte den samlede lønramme for de øvrige områder. I den offentlige sektor er det staten, der traditionelt er tildelt den rolle, men under OK18 viste det sig hurtigt at være en umulighed. CFUs organisationsmodel bygger på en reel musketer-ed, som indebærer, at der ikke kan indgås forlig med MS, hvis bare en af de tilsluttede centralorganisationer ikke kan tilslutte sig forliget. AC, LC (via SKAF) og OAO-S har altså alle en vetoret, når der skal sluttes en aftale med MS. Det krav, der blokerede for en aftale og et gennembrudsforlig, var CFU's krav om, at den betalte spisepause for de statsansatte havde status af et overenskomstgode, der ikke kunne opsiges af modparten uden at indgå en ny overenskomst på området. Lønrammens størrelse og ikke mindst MS' krav om indfrielsen af løftet fra OK15 om 'at lukke løngabet' havde også en afgørende betydning, men specielt AC, som er den store gruppe i CFU, kunne bruge sin vetoret og hindre et forlig, så længe problemet med spisepausen ikke var løst. De andre faggrupper, eksempelvis den store HK-stat, havde allerede den betalte spisepause som et overenskomstgode. Uenigheden mellem parterne gik derfor på, om AC historisk havde erhvervet den betalte spisepause som et overenskomstgode? En tvist om den betalte spisepause er det man i det fagretlige sprog kalder for en 'fortolknings'- eller en 'retskonflikt' og altså ikke en 'interessekonflikt', hvor parterne forhandler om en oprettelse eller en fornyelse af overenskomsterne. Retskonflikter løses ikke gennem overenskomstforhandlinger, men afgøres normalt via en voldgiftsret, nedsat til lejligheden, hvis afgørelser ikke kan appelleres. MS tilbød CFU at tage en voldgift på den betalte spisepauses status, men AC afslog det tilbud, da man af sine jurister fik den besked, at udfaldet af en voldgiftsret, ville være usikkert. Gik voldgiftsrettens afgørelse imod AC, ville det koste medlemmerne dyrt at forhandle sig til en betalt spisepause, da et sådant gode koster ca. 7 procent af en månedsløn. Så var det formentligt billigere at tage et slagsmål om prisen under OK18, hvor AC kunne få hjælp af sine venner i CFU og den øvrige fagbevægelse. Dog har vores interviews vist, at OAO-gruppens solidaritet med AC ikke rakte så langt, at man var villig til at gå ud i en konflikt for at få akademikerens betalte spisepause skrevet ind i deres overenskomst.

AC kunne bruge deres vetoret i CFU til at blokere for et gennembrudsforlig i staten, men det kunne DLF også gennem LC for derigennem at holde presset på KL for at få en ny arbejdstidsaftale i en overenskomstaftale på det kommunale område. AC og DLF/ 
LC på det statslige og kommunale område kunne således holde hinanden i skak og blokere for et gennembrudsforlig på det statslige område. Det blev derfor hurtigt klart, at OK18 ville få et andet forløb end de tidligere overenskomster. Sammenholdet i fagbevægelsen var større end under OK13 og OK15, jævnfør FF's 'politiske håndslag' og FF's og CFU's fælles henvendelse til arbejdsgiverne i oktober samme år.

Parterne forhandlede de tre knaster: spisepausens status, lærernes arbejdstid og lønrammens størrelse ved alle tre forhandlingsborde, og man kom ingen vegne. Fagbevægelsen havde udviklet et nyt stærkt sammenhold - man havde opfundet en atombombe, som en fagforeningsrepræsentant senere udtalte - men hvordan skulle der skabes forlig? Hvor skulle gennembruddet og dynamikken i forhandlingerne komme fra? Konflikten nærmede sig.

Den 21. februar indkaldte fagbevægelsen til demonstration i København, og lønmodtager- organisationerne begyndte at forberede sig på en konflikt. Fredag den 23. februar erklærede CFU's chefforhandlinger på det statslige område sammenbrud, og et par dage efter sker det samme på det kommunale og det regionale område. Helt efter hovedaftalens bestemmelser måtte fagbevægelsen varsle konflikt, og strejkevarslerne blev afleveret til arbejdsgiverne den 2. marts 2018 . Varslerne omfattede 10 til 15 procent af de ansatte i de tre sektorer, hvilket svarer til omkring 100.000 medlemmer. Transportområdet - statsbanerne, DSB og lufthavnene - ville blive lammet, og det samme ville ske med eksempelvis Veterinærområdet, som betød lukning af eksempelvis slagteriområdet. Det var altså ikke blot den offentlige sektor, men også den private sektor, der ville blive hårdt ramt af strejkerne, især på grund af strejkerne på transportområdet. Fagbevægelsen havde således valgt at strejke på områder, der kunne gøre ondt på dansk økonomi og dermed på regeringen.

Arbejdsgivernes svar på fagbevægelsens strejkevarsler kom den 7. marts. Sophie Løhde ville lockoute 120.000 statsansatte, hvis konflikten blev en realitet, og det var tæt på alle statsansatte, som talte 180.000. Senere samme dag fulgte KL og Regionerne op med at varsle lockout for henholdsvis 250.000 kommunalt og 70.000 regionalt ansatte. I alt 440.000 offentlige ansatte ville blive lockoutet, dvs. udelukket fra deres arbejdsplads, og lægges de strejkende lønmodtagere oven i, ville det blive 'The Big Bang', en storkonflikt omfattende stort set hele den offentlige sektor, et fænomen, der aldrig før var set i den offentlige sektors historie.

Fagbevægelsens nøje udvalgte nålestiksstrejker, der ville gøre ondt på især den private sektor og dermed dansk økonomi, blev mødt med en næsten totalomfattende storlockout af arbejdsgiverne. Strategien var, - som nævnt i vores interviews - at gøre konflikten 'kort og blodig'! En så omfattende konflikt ville hurtigt tømme forbundenes strejkekasser, hvilket så efterfølgende kunne føre til enten et hurtigt forlig eller et hurtigt lovindgreb.

Det er på sin vis konfliktens rationale: at være fredsskabende. Men måden, det sker på - processen - er ikke ligegyldig, og en så omfattende konflikt kunne sætte meget dybe spor og skade samarbejdet mellem parterne langt ud i fremtiden. Mange af de faglige ledere gættede på et hurtigt lovindgreb og udtrykte på den baggrund bekymring for den danske models skæbne i den offentlige sektor.

\section{Forhandlinger i Forligsinstitutionen}

Forhandlingerne i Forligsinstitutionen startede den 5. marts, og forløbet blev det læng- 
ste i Forligsinstitutionens historie. I mere end to måneder marcherede 300 mennesker ind og ud ad døren i bygningen på Skt. Annæ Plads i København, og selv om parterne ifølge Forligsmandsloven er underlagt tavshedspligt under strafansvar, fik offentligheden et rimelig godt billede af og indsigt $i$, hvad der foregik inde bag facaden. Medierne var massivt til stede i døgnvagt, ikke mindst TV2News, som mange af forhandlerne på trods af tavshedspligten - var i jævnlig kontakt med og dagligt forsynede stationen med oplysninger om parternes kravudveksling og status på forhandlingerne. Desuden var fagbevægelsens støtter massivt til stede, med kaffe, megafoner og ofte med orkester og sange. Et større og til tider festligt mediecirkus satte derfor sit præg på de offentlige overenskomstforhandlinger.

Det langvarige forhandlingsforløb i Forligsinstitutionen skyldes dels at parterne fortsat stod langt fra hinanden. Fagbevægelsens strategi med at forhandle de tre knaster ved alle tre forhandlingsborde komplicerede forhandlingerne yderligere. Solidaritetspagten betød, at forlig om de tre knaster skulle i mål på samme tid ved alle forhandlingsborde. Forligsmanden prøvede med forskellige kombinationer af forhandlingsmønstre, først de statslige forhandlinger, derefter kommunerne og regioner, senere kommunerne først, og til sidst alle tre sektorer på en gang. Men lige lidt hjalp det, der var ingen bevægelse, men offentligheden fik dog informationer om, at arbejdsgiverne i små bidder hævede lønrammeprocenten, så den nærmede sig de 8 procent.

Fagbevægelsens krav viste sig gennem diverse målinger at have massiv opbakning i offentligheden, og det er altid en godt rygstød for en forhandler at have opbakning i folkehavet, ikke mindst i en periode, hvor der ikke er langt til et folketingsvalg. Fagbevægelsen oplevede desuden en mobilisering $i$ medlemsskaren, som ikke var set siden kon- flikterne i 2008, og flere forbund fik en pæn medlemsfremgang under forløbet. Fagbevægelsen lagde yderlige tryk på arbejdsgiverne gennem et TR-stormøde i Fredericia den 22. marts, hvor ikke mindre end 10.000 tillidsrepræsentanter deltog. Det blev Danmarkshistoriens største faglige møde nogensinde (Høgedahl, 2019).

Forhandlingerne i Forligsinstitutionen havde udløb den 28. marts, og der var hektisk mødeaktivitet op til den deadline, men det lykkedes ikke at indgå et forlig, der kunne åbne spillet og skabe ny dynamik i forhandlingerne. Konflikten kunne så bryde ud efter Forligsmandslovens regelsæt, men forligsmanden valgte - ud fra de muligheder, som forligsmandsloven giver, og ud fra en vurdering af forligsmulighederne og de samfundsøkonomiske konsekvenser af en konflikt - at udsætte de varslede strejker og lockouter i op til 14 dage. Den nye deadline for, hvornår et gennembrud og et/flere forlig skulle være på plads, var nu den 17. april. Den hektiske mødeaktivitet fortsatte i Forligsinstitutionen, og da den nye deadline nærmede sig, blev der i Forhandlingsfællesskabets bestyrelse afholdt et møde i DSR's lokaler tæt ved Forligsinstitutionen, som på mange måde blev afgørende for det videre forløb. Der var kun 24 timer til deadline for forhandlingernes afslutning, og på mødet gjorde LO-gruppen det klart, at kun en manglende opfyldelse af gruppens lønkrav ville kunne få LO-forbundene til at gå ud i en konflikt. Her undsagde LO-forbundene en tolkning af solidaritetspagten, der gik ud på, at man på tværs af forhandlingsfællesskaberne skulle sikre målopfyldelse på de tre knaster på en gang: 'En løsning for alle'! LO-forbundene kunne dog henvise til FF's erklæring fra 2. marts 2018 - refereret ovenfor - hvori der står, at man er parat til at gå i konflikt for at sikre en reallønsudvikling som den, de privatansatte oplever. De øvrige lønmodtagergrupper var uenige i den 
fortolkning af erklæringen fra 2. marts, og henviste til, at der i erklæringen også stod, at arbejdsgiverne heller ikke i forhold til den betalte spisepause, som har tæt sammenhæng med de statslige forhandlinger, har vist vilje til at finde løsninger, som kan betrygge de ansatte i kommuner og regioner. Men det afgørende ved LO-gruppens tilkendegivelse var, at hvis det alene var lærernes arbejdstid eller den betalte spisepause, der stod i vejen for et forlig, så ville LO-folkene blive ved forhandlingsbordet, og gå efter en aftale uden om AC og FTF. Der var nu åbnet for et nyt forhandlingsspil, som rummede de forligsmuligheder, som ikke havde været til stede i flere måneder. Dog ville det skabe splittelse i fagbevægelsens sammenhold.

Deadline for forhandlingerne var den 17. april kl. 24.00, og netop den dag bliver særdeles hektisk, da ingen forlig er indgået. Forligsmanden kan vælge at forlænge forhandlingsmulighederne med yderligere 14 dage, og en samlet arbejdsgiverfront kommer i sidste øjeblik med det såkaldte 'midnatstilbud', der bl.a. indeholdt en lønramme på 8 procent. At tilbuddet blev kendt i samme øjeblik, det var afleveret til pressen, hænger sammen med, at det øjeblikkeligt blev lækket til TV2News, der permanent var parkeret foran Forligsinstitutionen. CFU afviste 'blankt' tilbuddet efter en meget kort læsepause, da der bl.a. ikke var en løsning på hverken den betalte spisepauses eller lærernes arbejdstidsregler. Forhandlingerne kunne fortsætte ud på natten, da forligsmanden havde 'sat uret i stå', og det derfor var muligt at overskride deadline. Men det var stadig ikke muligt at indgå et samlet forlig for alle områder eller blot et forlig på et enkelt område, som kunne åbne op for de fastlåste forhandlinger ved de andre forhandlingsborde. Konflikterne skulle derefter planmæssigt iværksættes, med mindre forligsmanden valgte at forlænge fristen for at indgå forlig med yderligere 14 dage. Forligsmanden valgte den sidste mu- lighed, da hun skønnede, at der stadig var forligsmuligheder, og at en altomfattende storkonflikt ville have store negative samfundsøkonomiske konsekvenser.

\section{Gennembrudsforliget}

Den nye deadline blev - af alle dage - sat til den 1. maj, der som bekendt er arbejdernes inter- nationale kampdag. Arbejdsgiversiden kunne på den baggrund frygte, at det ville motivere lønmodtagersiden til at intensivere kampen for sine krav endnu mere, om nødvendigt gennem en spektakulær storkonflikt. 1. maj talerne kunne blive historiske. Men sådan gik det ikke.

Fronterne ved forhandlingsbordene $\mathrm{i}$ staten og kommunerne virkede fuldstændigt frosset til uden udsigt til optøning. I staten, fordi CFU-siden ikke ville betale for en spisepause, som de mente at have betalt for mange overenskomstrunder siden. Omvendt ville MS ikke afgive et gode til CFU, som de mente, der ikke var betalt for. Ved det kommunale bord var stridspunktet især DLF's arbejdstidsmodel, hvor DLF kæmpede ultimativt for en kvartalsnorm og KL - lige så ultimativt kun ville tilbyde en halvårsnorm. På det mindste område - Regionerne - var der mindre dramatik, og de udmeldinger, der løbende kom fra chefforhandlerne, lød på, at 'det gik godt, og at man ikke var langt fra hinanden'. Spisepausen var ikke det samme store problem i regionerne, da mange faggrupper havde den betalte spisepause, som et overenskomstgode. Og da problemet med DLF's arbejdstidsregler skulle løses ved det kommunale bord, var det - i hvert fald efter LO-gruppens mening - ikke et problem, der kunne blokere for forligsmulighederne ved det regionale bord.

LO-folkene, primært FOA's formand Dennis Kristensen havde allerede før den 17. april tilkendegivet, at parterne var kommet tættere på hinanden, ikke mindst når det 
gjaldt lønrammens størrelse. En lønramme på 8 procent over 3 år var meget tæt på det mål, som man havde sat sig. Faktisk peger flere informanter på, at LO-gruppen var klar til at acceptere en samlet lønramme på 7,9 procent (Interviews). Når det gjaldt sikring af den betalte spisepause, bad LO-forbundene sine jurister om en vurdering af arbejdsgivernes formulering af 'betryggelse af spisepausen': var de juridisk holdbare og bindende, kunne de holde i en voldgiftsret? Den forsikring gav LO's jurister, og det meddeler LO-gruppen til offentligheden mandag den 23. april.

LO-folkene ville derfor ikke betale en del af lønrammen, for at få en 'ekstra betryggelse', og de ville derfor heller ikke gå ud i en omkostningstung storkonflikt for at kæmpe for, at AC-grupperne - uden at betale - fik spisepausen indskrevet $\mathrm{i}$ deres overenskomst. LO-gruppen havde under de seneste ugers forhandlinger fået det indtryk, at flere FTFog AC-forbund nu bevidst styrede efter en storkonflikt, grebet af stemningen fra medierne og ikke mindst tilråbene og opbakningen fra demonstranterne foran Forligsinstitutionen.

LO-gruppen havde derfor på det tidspunkt aftalt at gå solo, hvis lejligheden bød sig, og det skete natten til den 26 . april ved det regionale bord. OAO indgik et (del)forlig med regionerne, og det skete en sen nattetime efter at FTF- og AC-forhandlerne har forladt forhandlingsbordet, fordi de ikke var tilfredse med det udspil, som arbejdsgiverne var kommet med. Forliget kom efter sigende i stand efter et opkald fra LO-formanden Lizette Risgaard, som kilder oplyser, forhindrede Forligsmanden i at sende forhandlerne hjem, og dermed afværgede et sammenbrud meget tæt på den absolutte deadline (Interviews).

Delforliget indeholdt en samlet lønramme på 8,17 procent, en ligeløns- og lavtlønspulje på 0,35 procent, pulje til organisationsspe- cifikke forhandlinger på 0,35 procent. Privatlønsværnet blev fjernet, regningen for løngabet fra OK15 blev slettet, betryggelse af den betalte spisepause, projekt om forbedring af arbejdsmiljøet og en ny ferieaftale. Aftalen matcher tydeligt LO-gruppens topprioriterede krav om reallønsforbedringer, der følger den private sektors lønudvikling. Specielt FOA's medlemmer, der både er kvinder og lavtlønnede, fik meget med hjem, og FOA's forbundsformand Dennis Kristensen - og de øvrige LO-forbund - var derfor meget tilfredse med forligets indhold.

FTF- og AC-forhandlerne var derimod bestemt ikke tilfredse, især ikke med teksten om betryggelsen af den betalte spisepause, og fagbevægelsens chefforhandler i regionerne, Grethe Christensen, havde forladt forhandlingsbordet sammen med AC, medens LO-gruppen var blevet siddende og lukkede aftalen. I offentligheden - og dagen efter af en DSR-repræsentant direkte på TV foran Forligsinstitutionen - blev Dennis Kristensen beskyldt for at have forladt forhandlingerne, brudt solidaritetspagten og dermed forhindret, at en samlet fagbevægelse havde fået opfyldt alle sine krav. Dennis Kristenses forsvarede sig med, at han, jævnfør ovenfor, tidligt havde meddelt FF's bestyrelse den 16 . april, at kun lønrammen, og ikke den betalte spisepause, var et konfliktudløsende krav. Desuden var det aftalt i 'seksbanden' - formændene for de seks forhandlingsdelegationer - at ' vi skal indgå forlig, der hvor det er muligt, hvis en samlet løsning ikke kan lade sig gøre', (Dennis Kristensen, Politiken 27.4.2018). OAO's forlig på det regionale område skabte stor forstration blandt de øvrige forbund. Det var efter deres mening fællesskabet, der havde bragt lønrammen på 8,17 og sikret alle de goder, som OAO nu tog hjem alt i mens de øvrige forbund ikke var kommet i mål med deres krav. 'De tog pengene og løb', udtaler en forhandler. Frustrationen blev yderligere forstærket ved, 
at OAO kun udgør den lille gruppe på regionernes område, hvilket kunne opfattes som en stor provokation. Det har været en stor intern diskussion i fagbevægelsen, om de øvrige forlig faldt på plads enten på grund af eller på trods af OAO-forliget på det regionale område.

Arbejdsgiversiden, her Sophie Løhde, havde læst spillet rigtigt, og set, at det eneste sted, hvor der var en åbning, var i regionerne, hvor LO-gruppen ville acceptere en aftale, hvis dens topprioriterede krav - lønrammen - var lidt over 8 procent. Sophie Løhde havde fra sin tid som sundhedsminister etableret gode personlige relationer til FOA og Dennis Kristensen, og de havde under forløbet på tomandshånd fået talt sig ind på, hvor meget et forlig i regionerne skulle koste. MS har fuld kontrol med RTLN via vetoretten (jf. ovenfor).

\section{Slutspillet, resultatet og urafstemning}

Gennembrudsforliget var nu skabt, selv om det kun var et (del)forlig på regionernes område. Lønrammen på de 8.17 procent lå fast, det var kun et spørgsmål, hvad pengene skulle bruges til. To dage efter indgik KL en aftale med sin modpart på hele det kommunale område. De øvrige forbund i regionerne lavede også forlig dog med forskellige modeller, hvad angik den betalte spisepause. Endeligt blev der om aftenen den 28. april indgået et forlig på statens område, med den samme lønramme som i regionsforliget, men hvor den store AC-gruppe måtte betale for at få indskrevet den betalte spisepause i deres overenskomst med 0.3 procent af lønrammen.

Forliget på DLF's område kom også i hus sammen med forliget på det kommunale område. KL og LC indgik - højest overraskende - et forlig om at nedsætte en kommission, der skulle kulegrave hele undervisningsom- rådet, herunder arbejdstidsregelsættet og andre ting, der fremmer god undervisning, og 'se på skolen med nye og friske øjne'.

Den mest langvarige overenskomstforhandling i den offentlige sektors historie endte således med forlig hele vejen rundt til trods for mange kriser og sammenbrud undervejs, hvor man i slutfasen balancerede på randen af en altomfattende storkonflikt. Når resultatet skal vurderes, må man nødvendigvis tage udgangspunkt i dels parternes kravsformulering og de rammebetingelser, som omgav overenskomstspillet. Lønmodtagersidens topprioriterede, generelle krav, der dækkede alle medlemmerne i de tre sektorer, var en lønramme, der matchede den skønnede lønudvikling i den private sektor for de næste tre år. Den aftalte lønramme på 8,17 procent må siges at opfylde det krav, da den faktiske lønstigning på DA's område i slutningen af 2018 var på ca. 2,5 procent, og i 2019 og 2020 forventes at stige med mellem 2,5 og 3,0 procent. Men det er værd at huske på, at den gældende reguleringsordning under alle omstændigheder vil sikre en parallelitet mellem den private og den offentlige sektors lønudvikling på mellemlang sigt. Lønmodtagersiden fik en anden ikke ubetydelig gevinst med hjem, idet arbejdsgiversiden afskrev 'gælden' fra OK15, og privatlønsværnet blev byttet ud med den hidtil gældende reguleringsordning. Desuden fik man opfyldt sit krav om en lavtløns- og ligelønspulje, og den betalte spisepause blev sikret i forskelligt omfang. AC fik den indskrevet i sine overenskomster mod at betale 0,3 procent af lønrammen, medens LO- og FTF-grupperne fik indskrevet nogle nye betryggelsestekster uden betaling. Endeligt fik lønmodtagerne også nogle tryghedsgoder og et fælles projekt om at forbedre arbejdsmiljøet. Men DLF og det øvrige undervisningsområde fik ikke erstattet lov 409 med en overenskomst. Forhandlingerne mellem DLF og KL blev sat på stand by, men problemerne 
blev ikke løst, og KL og DLF skal tilbage til forhandlingsbordet i 2021 på baggrund af Lærerkommissionens anbefalinger.

Arbejdsgivernes hovedkrav var en 'ansvarlig lønramme', der ikke ville skabe problemer for den private sektors muligheder for at kunne rekruttere kvalificeret arbejdskraft og svække sektorens internationale konkurrenceevne. Desuden skulle den nye overenskomst også skabe muligheder for, at den offentlige sektor i fremtiden kan rekruttere den nødvendige arbejdskraft, ikke mindst i kommunerne, der leverer hovedparten af velfærdsydelserne. Den aftalte lønramme landede på 8,17 procent, hvilket var en anelse over, hvad arbejdsgiverne havde ønsket sig, hvor den private sektors gennemsnitlige lønstigningstakt i 4. kvartal 2018 lå på 2,7 procent. Men aftalen afspejler dels de gunstige økonomiske konjunkturer, dels at et folketingsvalg nærmede sig, og at en altomfattende storkonflikt ville skabe usikkerhed frem mod et Folketingsvalg. Arbejdsgiverne måtte også opgive privatlønsværnet og kravet om lukning af løngabet, og man fik kun en beskeden pris for at sikre især akademikerens spisepause. Da arbejdsgiverne heller ikke fik indløst deres krav om en mere fleksibel arbejdstid og en mere lokal og individuel løndannelse, må en samlet vurdering af overenskomstresultatet derfor blive, at lønmodtagerssiden har mest grund til at være tilfredse med udfaldet af OK18.

At lønmodtagersiden var tilfredse med overenskomstresultatet afspejler sig også i dels en rekordhøj stemmedeltagelse, dels en meget høj Ja-procent. Samlet set stemte 87,5 procent ja på det statslige område, mens henholdsvis 89,5 og 90,1 procent stemte ja på den kommunale og det regionale område. I FOA stemte 95 procent ja, i HK stemte 94 procent ja og i Sundhedskartellet var ja-procenten på 93 procent. Kun de ansatte ved lokalbanerne stemte nej, men kom også med efter en ny forhandling. På DLF's om- råde stemte man - som de øvrige forbund i kommunerne og regionerne - forbundsvis, og ja-procenten var her på 74,6 procent. DLF fik dermed opbakning og mandat til Lærerkommissionen, som en løsning på meget vanskelige forhandlinger.

Arbejdsgiversiden sagde også ja via deres kompetente forsamlinger, og arbejdsfreden sænkede sig dermed over hele det offentlige arbejdsmarked efter rekordlange, udmarvende og højdramatiske forhandlinger.

\section{Konklusion og perspektivering}

OK18 fik et helt specielt forløb, fordi begge parter i særlig høj grad blev indhentet af resultater fra tidligere overenskomstfornyelser. Arbejdsgiversiden blev ramt af en boomerang fra OK13, da den samlede lønmodtagerside krævede, at resultatet af storlockouten og regeringsindgrebet på undervisningsområdet - lov 409 - skulle erstattes af en overenskomst med nye arbejdstidsregler. Forløbet viser tydeligt, at der er en stærk institutionel stiafhængighed i aftalesystemet, hvor tidligere forhandlinger spiller en afgørende rolle for de aktuelle. Lønmodtagerorganisationerne blev ramt af resultatet af OK15, hvor man på statens område havde skrevet under på en hensigtserklæring om, 'at lukke løngabet mellem de offentlige og private lønmodtagere i løbet af overenskomstperioden fra 2018'. I tilgift kørte parterne en konflikt op om den betalte spisepauses status: En overenskomstret eller en kutyme/personalegode inden man overhovedet fik startet forhandlingsforløbet. Dertil kom slagsmålet om størrelsen af lønrammen for de næste tre år.

Fagbevægelsen havde inden OK18 fået etableret en større grad af koordinering og sammenhold på tværs af forhandlingsfællesskaberne, og dermed opnået at afbalancere magtforholdene i forhold til arbejdsgivermodparten til deres egen fordel ved at 
aktivere nye og stærke organisatoriske magtressourcer. Mobiliseringen var også stærk, og den trak sin næring fra en generel utilfredshed blandt de offentlige ansatte under parolen: 'Nok er Nok'. Iflg. Kelly (1998) er mobilisering netop mulig, hvis en gruppe oplever en uretfærdighed, der kan italesættes og tilskrives en anden gruppe i dette tilfælde de offentlige arbejdsgivere; også selvom mange af frustrationerne gik på forhold (fx omprioriteringsbidraget eller normeringer), som ikke er en del af forhandlingerne ved overenskomstbordet. Den stærke mobilisering havde også indflydelse på forventningerne til udfaldet af forhandlingerne. Medierne, og særligt de sociale, blev brugt aktivt. Vurderingen er, at det i høj grad var fagbevægelsen, der vandt slaget i medierne og dermed dominerede den kommunikative magtressource. Det blev særligt tydeligt $\mathrm{i}$ forhold til diskussionen om løngabet.

Omvendt betød udviklingen af solidaritetspagten og senere musketereden, at forbundene og forhandlingsfællesskaberne i nogen grad lagde hinanden i benlås og dermed forhindrede den fleksibilitet og manøvredygtighed, der var en forudsætning for at give indrømmelser og lave et gennembrudsforlig. Fagbevægelsen brugte den institutionelle magtressource via veto-punkter til at presse arbejdsgiverne. Man kom derfor meget tæt på en altomfattende storkonflikt. Diskussionen mellem LO-gruppen på den ene side og FTF- og AC-gruppen på den anden side afspejler, at solidariteten på tværs af de tre hovedgrupper kun kan holde, så længe hver enkelt gruppe føler, at deres medlemmers interesser bliver tilstrækkeligt tilgodeset. FTF-forbundene var sammen med AC-forbundene indstillede på - om nødvendigt - at kæmpe videre på spørgsmålet om spisepausens status, medens de LO - forbund under forhandlingsforløbet havde tilkendegivet, at for dem var alene lønrammens størrelse et konfliktudløsende krav. Det er et hypotetisk spørgsmål, om Danmark var endt i en storkonflikt, hvis det ikke var for (del)forliget på det regionale område. Interessemodsætningerne mellem de lavt - og de højtlønnede forbund kom dog tydeligt frem i slutningen af forløbet, og OK18 endte dermed i den allersidste fase med at blive en klassisk kamp mellem lønmodtagerforbundene om fordeling af det samlede overenskomstresultat. OAO's forlig på det regionale område skabte stor frustration blandt de øvrige forbund. Men alt i alt indhøstede lønmodtagersiden nye erfaringer om, hvor langt de kunne komme med et øget sammenhold og tættere koordinering. Omvendt vil arbejdsgiverne givetvis i fremtiden få svært ved at acceptere et forhandlingsforløb, hvor flere af fagbevægelsens krav kan opfattes som ultimative og dermed konfliktudløsende.

Det lange forløb i Forligsinstitutionen viser også tydeligt, at det offentlige område er markant anderledes sammenlignet med det private. Læk af informationer fra Forligsinstitutionen var under OK18 stor. Forligsmanden fik heller ikke samlet alle i ét mæglingsforslag, hvilket formentlig hænger sammen med, at der ikke er den samme hovedorganisationsstruktur på det offentlige som på det private område. Det kan gøre det svært at få en udtrykkelig godkendelse af et samlet mæglingsforslag af parterne. OK18 viste dermed også, at det er yderst kompliceret at nå et samlet forlig i Forligsinstitutionen uden et retvisende forlig på statens område. Sammenkædningsreglerne i forligsmandsloven fungerer i den private sektor effektivt til at samle de områder op, som ikke kan nå til enighed. I den offentlige sektor betyder forhandlingsstrukturen, at forligsmandens mulighed for sammenkædning er vanskelig at gennemføre.

OK18 blev resultatmæssigt - på trods af det meget langvarige og dramatiske forløb - en traditionel vedligeholdsoverenskomst. Ingen nye samarbejds- eller forhandlings- 
aftaler, fleksible arbejdstidsregler eller nye lønsystemer, og specielt arbejdsgiversiden udtrykte frustrationer over, at lønmodtagersiden ikke har viljen til at levere input til en - efter arbejdsgivernes mening - mere dynamisk og effektiv offentlig sektor.

Udfordringen for den danske model i den offentlige sektor er derfor i fremtiden, at par- terne kan finde sammen i et tillidsfuldt samarbejde, hvor de kan indgå innovative aftaler, der tilfredsstiller både lønmodtagesidens krav om løn- og arbejdsvilkår, der matcher den private sektors, og arbejdsgiversidens krav om produktivitet, effektivitet og fleksible løn- og arbejdsvilkår

\section{REFERENCER}

CFU (2017). CFU's generelle krav ved aftale- og overenskomstforhandlingerne 2018, www. CFU.dk, tilgået 23.01.2019

Due, J. \& Madsen, J. S. (2009). Forligsmagere og forumshoppere: analyse af OK 2008 i den offentlige sektor. Djøf/Jurist-og Økonomforbundet.

Dunlop, J. T. (1958). Industrial relations systems. New York: New York: Henry Holt and Company.

DØR (2017). Dansk Økonomi, efterår 2017. Rapport. København: Rosendahl

Edwards, P. (2006). Power and ideology in the workplace: Going beyond even the second version of the three-dimensional view. Work, Employment and Society, 20(3), 571-581.

Forhandlingsfællesskabet. (2017). Generelle krav til KL ved overenskomstforhandlingerne 2018, www.Forhandlingsfællesskabet.dk, tilgået 23.01.2019 Hyman, R. (2008). The state in industrial relations (pp. 258-283). London: Sage.

Høgedahl, L. \& Ibsen, F. (2015). Konfliktrettens anvendelighed i den offentlige sektor set i lyset af OK13. Økonomi og Politik, 88(1).

Høgedahl, L. \& Ibsen, F. (2017). New terms for collective action in the public sector in Denmark: Lessons learned from the teacher lock-out in 2013. Journal of Industrial Relations. https://doi.org/10.1177/0022185617706425.

Ibsen, C. L. (2013). Consensus or coercion: Collective bargaining coordination and third party intervention.

Sociologisk Institut, KU.

Ibsen, F. \& Stamhus, J. (1993). Fra central til decentral lønfastsættelse - muligheder og konsekvenser: Djøf's Forlag.

Ibsen, F. \& Christensen, J. F. (2001). Løn som fortjent. Nye Lønformer i Den Offentlige Sektor: Djøf Forlag.

Ibsen, F., Høgedahl, L. K. \& Scheuer, S. (2016). Strikes in the public sector - Assessing the economic gains and losses of collectiv action. Transfer: ETUI. https://doi.org/10.1177/1024258916655709.

Jacobsen, K. \& Pedersen, D. (2010). Kampen om den danske model: Da Sosu'erne rystede det etablerede system. København: Information.

Kelly, J. (2012). Rethinking industrial relations: Mobilisation, collectivism and long waves: Routledge. https://doi.org/10.4324/9780203213940.

KL (2017). Generelle krav til Forhandlingsfællesskabet, www.KL.dk, 2018 tilgået 23.01.2019. Kochan, T. A., McKersie, R. B. \& Cappelli, P. (1984). Strategic choice and industrial relations theory. Industrial Relations: A Journal of Economy and Society, 23(1), 16-39.

Korpi, W. (1981). Sweden: Conflict, power and politics in industrial relations. Industrial Relations in International Perspective, 185-217. https://doi.org/10.1007/978-1-349-04442-9_5.

Kvale, S., \& Brinkmann, S. (2009). Interview: introduktion til et håndvoerk: Hans Reitzel.

Lévesque, C. \& Murray, G. (2010). Understanding union power: resources and capabilities for renewing union capacity. Transfer: European Review of Labour and Research, 16(3), 333-350. https://doi.org/10.1177/1024258910373867. 
Moderniseringsstyrelsen (2017). Generelle krav til overenskomstforhandlingerne, www.Moderniseringsstyrelsen.dk, 2017. tilgået 23.01.2019.

Nergaard, K., Alsos, K. \& Åsmund Arup, S. (2016). Koordinering av lønnsdannelsen innen de nordiske frontfagsmodellene. FAFO Notat 2016:25.

Pedersen, D. (1997). Forhandlet Forvaltning - en ny institutionel orden for den statslige løn- og Personalepolitik. Ph.D afhandling, Center for offentlig Organisation og Styring. København.

Pedersen, D. (1999). Det statslige aftalesystem. Fra central til lokal forhandling. 100-året for

Septemberforliget - Et festskrift. København: Schultz Information.

Petersen, H. (1987). Ledelse og loyalitet. Kollektiv arbejdsret $i$ den offentlige sektor. København: Akademiskforlag.
Pierson, P. (2000). Increasing returns, path dependence, and the study of politics. American political science review, 94(2), 251-267.

Regionerne (2018) Krav til Forhandlingsfællesskabet. https://www.fysio.dk/globalassets/ documents/ok18/regionernes-krav-til-forhandlingsfaellesskabet-ok18.pdf tilgået 01.05.2019. https://doi.org/10.2307/3089666.

Scheuer, S (2010). Decentralisering og ligeløn. Dilemmaer i den offentlige sektors aftalesystem.

Samfundsøkonomen, 4, 33-38.

Silver, B. J. (2003). Forces of labor: Workers' movements and globalization since 1870 Cambridge University Press.

Stamhus, J., Scheuer, S., \& Christensen, S. (2010). Tre strejker i det offentlige - en komparativ lønmodtager-investeringsanalyse. $\mathrm{Na}$ tionaløkonomisk tidsskrift, 147(3), 360-374.

Stokke, T. A. (1998). Lønnsforhandlinger og konfliktløsning: Norge i et skandinavisk perspektiv: Fafo.

Laust Høgedahl, lektor

Center for Arbejdsmarkedsforskning (CARMA), Institut for Statskundskab, Aalborg Universitet

e-mail: hogedahl@dps.aau.dk

Flemming Ibsen, professor emeritus

Center for Arbejdsmarkedsforskning (CARMA), Institut for Statskundskab, Aalborg Universitet

e-mail: Ibsen@dps.aau.dk 